\title{
ORGANIZATIONAL LEADERSHIP IN MOZAMBICAN BUSINESSES: SOME CONSIDERATIONS BASED ON A HERMENEUTICAL ANALYSIS OF DIRECT DISCOURSE
}

\author{
Ana Célia Calapez Gomes (Phd) \\ Centro de Estudos Africanos (CEA), Instituto Superior de Ciências do \\ Trabalho e do Emprego (ISCTE) ${ }^{1}$
}

\begin{abstract}
The present paper aims at delineating some of the themes of organizational leadership in Africa having as departure point a hermeneutical analysis of direct discourse. This investigation results from the content analysis of 30 semi-directed interviews with Mozambican and Portuguese organizational leaders working in Mozambique in two different towns, Beira and Maputo (Gomes, 2005). The interviewed leaders represent a highly diverse group of companies of different sizes, business areas, management systems and organizational cultures. This diversity helps bring together a variety of points of view, confront representations of leadership simultaneously from an emic and an etic perspective, and subsume a range of characteristics directly resulting from the analysis.
\end{abstract}

Keywords: leadership, Africa, Mozambique, authoritarian leader, paternalism.

Resumo: Pretende-se com este artigo apresentar alguns dos temas da liderança organizacional em África partindo da análise hermenêutica do discurso directo. Esta investigação resulta da análise de conteúdo de 30 entrevistas semi-dirigidas a indivíduos com

\footnotetext{
${ }^{1}$ Sponsored by the Fundação da Ciência e Tecnologia, Ministério da Ciência e Ensino Superior. Research Project "Managerial Configurations in Africa and Asia: structures, dynamics and meanings: A four nation study: Angola, Mozambique, Cape Verde and China" (FCT PTDC/AFR/72258/2006)
}

All electronic correspondence should be addressed to:

Ana Célia Calapez Gomes

ana.calapez.gomes@gmail.com 
funções de liderança de nacionalidade Moçambicana ou Portuguesa, mas actuando em Moçambique, em duas cidades, Beira e Maputo (Gomes, 2005). O grupo de líderes entrevistados é muito diverso, representando empresas de diferentes dimensões, áreas de negócio, sistemas de gestão e culturas organizacionais. Esta diversidade permite destacar uma série de pontos de vista, confrontar representações de liderança sob perspectivas internas e externas e, por fim, resumir uma série de características comuns, directamente resultantes da análise.

Palavras-chave: liderança, África, Moçambique, líder autoritário, paternalismo.

\section{INTRODUCTION}

The theme of leadership in Africa is a common one, but most of the literature about it is focused on political leadership (Fowler et al, 2002), dealing with such themes as state governance, power centralization, privatization of the state, and the problem of corruption. But leadership is also a fundamental variable in business and organizational settings independently of the geographic context. In the present state of globalization and growing interdependence and integration of world economies, the meanings associated with the function of leadership and its practice acquires a special value insofar as networks and all kinds of strategic alliances are the building ties of our present-day societies.

For decades, sociological, social psychological, and direct management literature debated the phenomenon of leadership as a question of the leader's character or the result of the circumstances (Cunha et al, 2004). Some models have been developed to assess and characterize leaders and leadership situations, but most of them are either too general to have a real heuristic value or are culturally biased, proposing "best ways" to lead without concern for the specific situation, and even less for the polysemic character of the concept.

This paper presents leadership in an African country in the first person discourse. This approach enables disclosure simultaneously of the diversity of the individual and the commonalities of the social agent from the point of view of grounded theory (Strauss, Corbin, 1990).

\section{Leadership}

Leadership is a fundamental management factor, even more determinant in a situation like the Mozambican, where the leader is invested with the double function of manager and father, considering simultaneously the interests and aspirations of highly-educated staff with 
their own identity dilemmas (between traditional prestige and western type careers), the aims of the majority low qualified workers, and of course, convenient rewards for the invested capital.

For the local manager, leadership in Mozambique prefigures an inconstant balancing between authoritarian actions and an excess of acquiescence, in order to gain subordinates' friendship. For the expatriate manager, it represents the exhausting work of translation of signs and meanings and the balancing between paternalistic temptation, fury at local Africans, and the conquest for legitimacy through shared knowledge and systematic interaction.

\section{The authoritarian leader}

The authoritarian leader is normally the one who has been dominated by subordinate's rebellion and decided on an aggressive behaviour and/or isolation, in order to maintain power.

"The boss is the boss! The boss commands, no one comes to him, no one says anything."

"(...) from tomorrow on, if one single box leaves the factory without a number, you are going to see what happens (...) If they know that they must do that work, they know that's my exigency, why don't they do it...do you see? They don't want to do anything or they even want to make a sort of sabotage, do you see?"

Or, it configures the charismatic patriarch of the small business.

"It was almost 5 p.m., 5 p.m. and the driver came with a problem (...) and as long as the car was broken, nobody left, they left at 9.pm. and at 7.30 a.m. everybody was present again. Of course I can arrange a form of compensation, but no... They never asked for it (...) nobody leaves as long as I am in my office; as long as I don't come down to go home, nobody leaves. That's it. I have educated them like this and they do it....".

\section{Respect for the leader}

Respect, not fear, is reserved for a kind of respectful and gentle, but firm leader.

"(...) we work very much on this basis, close to people, that's right? (...) People respect me, I have never had any problem of disrespect from a worker (...)." 
“ (...) I don't shout, I don't insult anybody, (...) if I have something to say to the person, I call him inside. I don't shout out, no, no, I call him inside (...) and I tell him what I have to say. My son, look here, life is like this, well you are the one who decides what you want, that's it, and after that he chooses to amends his behaviour or not."

\section{Leader's external signs of prestige}

Respect due to the person of the leader manifests itself through the externalization of the leadership condition, be it through the ostentation of privileges:

«(...) to be a chief, using a different uniform (...) formal authority issues are important, workers wear a specific colour, and team leaders wear another, (...)".

Or, be it by asking or accepting respect or even submission's manifestations from subordinates:

"(...) the kind of idea that respect for the leader is due through some kind of gestures, external manifestations, still exists in people, they look for a leader....that's it....that commands, that imposes, (...)".

\section{The leader's charactheristics}

What's the ideal picture of a leader that comes out of discourse? What's the most desirable kind of leader? Answers point out clearly for a strong relational type of leadership. But how does it materialize on the field? And what are the most desirable characteristics of a leader?

\subsection{Tolerance}

People wait tolerance from the leader, although limits to tolerance are insofar accepted. These limits seem to be more personal than institutional. Even when formalized, limits to tolerance may be legitimately broken by leader's will.

Tolerance in face of worker's mistakes is often referred to. Punishment is always a last resort, preferably used only after reiteration, except when the fault is to serious even for the leader's own code of values, as well as for the society's code of values. Frequent use of punishment (even on the strict respect for the established norms) is always associated with cases of dysfunctional management. 
"A failure...er.... it depends on....on the worker. But normally, er...the first mistake, I speak to the worker, second mistake, I speak to him again, I try everything possible, I teach again, I ask again why has he done wrong, why can he not do it and, of course.... if the mistakes are to much, then I change his working position."

"For instance, there are things I can not tolerate. For instance, if I catch someone stealing, ahh, he has no excuse, the one caught stealing goes, leaves the company. Er..., if for instance, someone makes some little mistake, then, it is not to be condemned, is it? I call him, isn't it? I give him a little brain wash and I tell him: kid, you know next time, next time you have no excuse."

\subsection{Affective relation}

People want that the leader to know absolutely everybody who works with him well enough, so that he doesn't even need to ask what his subordinate's problems and needs are.

" (...)it is relevant to have a strong relationship between management and the workers, at every level. If this relationship exists, we don't really need to ask anymore."

"When this is not the case, it is because people don't know each other well. So,.... When people don't know each other well, people don't understand each other, there are many discipline problems, management must be the administrative way, so there is a leader's tendency for authoritarianism, legalism, (...)."

\subsection{Proximity, openness and availability}

What exactly shapes this involvement, the solicited affection, or friendship? And how can such an intimate human knowledge be reached in the daily work practice, a knowledge which dispenses the leader needing to ask any of his subordinates about their problems? To answer these questions it is necessary to understand the way in witch the relationship between distance and proximity is perceived in Mozambique.

A great respect is due to the leader's person, including some ostensive forms of deference, which leads to a big distance between who leads, and who follows. But simultaneously, leader's proximity to all and each of its subordinates underlies the legitimacy of his authority and the right to a respectful distance. In other words, the leader wins the right to the distance conferred by authority's prestige insofar as he becomes close to 
his subordinates, until intimacy. Acting otherwise the leader does not win a respectful distance, but seclusion induced by fear and despise.

"Personal problems, even intimate problems.... I attend everyone, everyone without discrimination."

"I don't only speak only with my direct subordinates. I have meetings with all levels at the company, (...) I speak with all people so that everyone is perfectly conscious that I am always accessible."

"So, here you can not be a paper manager, a portfolio manager, here you must be a reality manager (...) a manager adapted to the African reality. And this means being always present. This means listening to everything."

The leader's proximity and availability may even be physical, when barriers in working space are eliminated.

"No, there are no doors, it is an open space, people see us, we have nothing to hide, and they can always come and bring the relationship with them."

This kind of openness permits an effective collective control; which seems to be quite appreciated, precisely because it contributes to reduce an always present sense of suspicion, that someone could be doing something secret to harm someone else.

“(...) workers are all concentrated in one single room. They work, they work near each other, so that anyone's mistakes are seen by everybody and, sometimes, my intervention is needed to correct the mistake and is held in the presence of everyone, that's it? So, there is a great homogeneity in the group, I mean, there is no possibility that er...some uncontrolled and hidden behaviours emerge."

\section{Power centralization}

Power centralization in Mozambican companies manifests itself through two confluent paths. On the one hand, the CEO practices a close proximity politic towards employees in general, which annul the competence space of intermediate chiefs, since the possibility of solving "placed" problems is a legitimacy factor and a way for power consolidation, always linked to regard and recognition.

"I think sometimes, as a CEO, that when I receive a simple worker (...) I am perhaps taking away the authority of those who are in the middle. I am not giving them the opportunity to be heard, to be 
consulted. So then, the worker, from the beginning (...) is unable to see his direct chief as a person capable of solving his problems."

“(...) those who decide like this, neglecting all the other hierarchy levels, even when they were recommended by them, are those who want to be individual heroes, because it means....my department chief was not able to decide, have you seen, the CEO have already decided! He is much more human ...yes...yes...that one is good for nothing...that one...!"

On the other hand, the relationship between the leader and the subordinate is based on trust and mutual acquaintance, so that the worker always looks for someone he knows. Much of the intermediate chiefs are young graduated staff members, unlike CEOs, who still owe their positions due to longevity or political trust. Most of the workers are acquainted with the CEOs, but not with their young direct managers.

\subsection{The line manager}

Centralization on the top of the pyramid has as consequence the emptying of the hierarchical line. But this one is occupied by individuals with leadership functions, which they are frequently unable to carry out. The attitude of the CEO itself in these cases is decisive. Normally he is responsible for the investiture of formal and factual authority in line managers, and much of this process depends on his own will.

"If line managers are respected or not, it depends on the will of the director himself. So that, the director sometimes imposes that authority, imposes the authority, he speaks with subordinates and says: look, those ones are chiefs from today on, if you have any questions, don't come and talk with me, talk to your chief. So that, in this moment, line managers win a little more....authority."

Nevertheless, the attitude of the line managers themselves before the situation also diverge, swinging between the natural acceptance of the transmition function:

"So, people come directly to their chief. People must explain themselves, they fill in the internal forms (...) the chief gives his opinion and goes directly to the finance director, (...) by the norm (...) and goes to the CEO for dispatch."

"We must be always open and listen to what people want to say. We can pass it to the hierarchy, so that the hierarchy may solve the problems." 
Or the silent anger, which may take the form of conspiracy:

"And people are carrying another conflict with them; they aspire for power, because they know what they know (...). So, when they feel that they know more than those who are above them, they remain apathetic to their orders, and as they can not show what they know, and at the top there is no critic acceptance, they remain in silence, a very dangerous silence, so then they break the communication between the top and the bottom."

And also aggressive authoritarianism as a form of hiding their own insufficiencies:

"(...) because there is also something that they [subordinates] notice, there is also something that they notice....it is that such managers also, when they are is a position, they think they are,... for them like...and they notice: ehe, look at that one, because he arrived there [a leadership position], he is dealing with us this way (...)".

\section{Knowledge and physical presence as power legitimating factors}

One of the most referred authority legitimating factors, beyond physical proximity and affective relationship, is knowledge; knowledge in the sense of competence for doing things, and competence to teach how to do things.

"Er...., I tell someone to do some kind of work and he begins to do $i$, and begins to do it wrong. I say: my son, this is not the right way. And he doubt it one way or another. Then I take the job in hand and I do it and I show how it is done. (...) After that (...) I enter in the factory and everything I say is sacred."

"To be respected? You must work harder then the others and show how things done (...) you must teach....er....you must teach everything."

The physical presence of the leader is often interpreted as a sign and evidence of his interest and engagement in the company. This transmits a sense of security and stimulates worker's participation.

"Being always present is a point of honour for me. They must feel that the boss, when it is...that they must loose a weekend, it is for us all to work together. It is a matter of honour for me to follow the job, to work together with them. It is a form of stimulus." 


\section{Protectionist paternalism}

Paternalism is a domination form based on direct personal dependency ties between individuals, in which the patron assumes paternal functions towards his protégé or client, protecting him, acting as a guardian and redistributing the means necessary to his sustenance (Léna, et al, 1996; Hernandez, 1998). Many implicit and even explicit references to this type of domination were found. They have normally a benevolent and caring meaning. The company is clearly identified with, or emerges in the direct continuity of the family, in its role of framing of the individual. The boss/ administrator is the redistributive father, the "last resource" in face of uncertainty and poverty:

"What they want from us. Er...may be, er... it is, to be the strong anchor. I mean, the last resource....there is a support, (...)”.

This convergence between the position of the father and the boss is so obvious that the leader may even be asked to zeal for the household expenses of the subordinates.

"He has a wage of 400 contos [thousand Meticais]: and he may say, boss, give me only, give me only 100... give me only 50 now because if I take everything home, my wife will spend my salary in two weeks. So, I pay to him his salary in pieces."

The circumstances themselves, extreme poverty, very low wages, force the adoption of protective measures towards employees. This kind of paternalistic management form manifests itself through extra-salary monetary support, cash advances and loans:

"I don't know, some times I prefer to lend my own money, and tell them: look, I am going to lend you money, but it is my money. The company doesn't give cash advances, but I see that you are in trouble. (...) But it is me; it is not the company that is giving to you, always giving to you (...)."

It manifests itself also through personal gifts, which refusal may be extremely bad accepted:

"Sometimes they contact me to ask, because a relative died, they need some 5 kilogram of sugar, for the mass...and everything. Look, it is 5 kilogram of sugar, it is nothing, but the word no....to say no, without understanding his worry, may hurt him for the rest of his life and hurts the entire work force, because the workers begin to say: he has done it to him, he will do it to us also!" 
Illness support:

"I also give them medicine. Always, when they come with a prescription or some problem, I try to help them; I try to do my best."

Food support:

"That's it you know, and also sometimes,... when there is a party, on Workers Day, Christmas, Easter, New Year. Ok, also, you may kill a little goat, or you may kill a little pig, that's it?"

And even personal and moral support:

"The driver has been ill, and... he called me telling me that he was in the hospital, I went visit him sometimes at the hospital. I told my secretary to buy milk and something else... and take it there. Of course I deducted it at the end of the month from his wage, but this is not the problem, the problem is really for the person to feel that.... Ok, that he belongs to the organisation, to us, that's it? And this kind of things is tremendously appreciated."

\section{Conclusions and implications}

From the analysis of some of the meanings of the variable Leadership in organizational settings in Mozambique we may conclude that there are several contextualised interpenetrations and reinterpretations of the function in the ambit of pre-industrial as well as industrial management models (taylorist and burocratic type). This process leads to a complex of organizational practices and leadership postures and representations, which may reveal some connection points with post-industrial organisation forms, as well as other that completely deny it.

The shading of the frontier between work and non-work, between domestic and professional settings is a common characteristic of pre- and post- industrial universe (Castells, 1996, Vallade, 2004). Apparently, industrialization and burocratization of organizations was not able to eliminate this facet, which on the contrary, is probably experiencing a kind of renaissance. Following the same path, it may be referred to some time and functional flexibility, as well as some participation that goes beyond the formal meetings. The question here is the probable link of the referred characteristics and practices and the notion of belonging to the patriarchal family, which implies, at least, two problems: the centralization of power in the person (not always the function) of the $\mathrm{CEO} /$ father, with all the consequences for the hierarchical line, responsibility, or even matricial project management models; and the 
closing of the organization/family in itself. The network organization, namely the kin network, is a characteristic of the so called traditional organizational models, but apparently the burocratization process and the formal hierarchy introduced by the colonial industrial organization broke the external ties of the network. As a consequence, it maintained the internal network in turn of the $\mathrm{CEO} /$ patriarch, but thrown away to informality all the external ties. In this way, and exactly in opposition to the post-modern networks of autonomous individuals and/or organisations, temporarily linked by common interests and shared objectives, we find internal networks, at least formally closed, and centred on the person or the function of the leader. In this kind of organisations, individual participation, even when active, is induced and motivated through the affective bond toward the person, which embodies all the formal power inside the organization.

There are some very interesting lines of study that may bring some new insights in this problematic, the idea of the materiality of social capital (Engeström, 2000) and the concept of Ubuntu (Nussbaum, 2003), a word that transmits the idea of interdependency. Both deal with cooperation and the enlargement of networks. In the case of Ubunbtu, in spite of the humanist and relational meaning of the concept, its reinterpretation on the present context, may broaden the traditional notion of interdependence (focused on kin) giving it a global meaning and helping to bring flexibility, participation and relational competences outside the strict borders of a specific organization. 


\section{REFERENCES}

CASTELLS, Manuel (1996), The Rise of the Network Society, Malden: Blackwell Publishers

CUNHA, Miguel et al (2003), Manual de Comportamento Organizacional e Gestão, Lisboa: Editora RH

ENGESTRÖM, Yrjö (2000), "On the materiality of social capital: an activity-theoretical exploration", Conference on "Collective Cognition and Memory Practices: Building the Infrastructures of Distributed Collective Activity", Paris, 19-20 September (draft paper)

FOWLER, Alan et al (2002), "Determinants of civic leadership in Africa: an exploratory study of NGDO's in Kenya", $5^{\text {th }}$ Conference of the International Society for Third Sector Research, Cape Town, 7-10 July retrieved on January 10, 2006 from www.jhu.edu/ istr/conferences/capetown/volume/fowleretal.pdf

GOMES, Ana (2005), A lógica do afecto: Discussão em torno das linhas de força da gestão de recursos humanos nas empresas portuguesas em Moçambique, Phd Dissertation, Lisboa: ISCTE

HERNANDEZ, Émile-Michel (2000), "Afrique: l'actualité du modèle paternaliste», Revue Française de Gestion, Mars/Avril/Mai, 98-106

NUSSBAUM, Barbara (2003), "Ubuntu and business: reflexions and questions”, Perspectives, World Business Academy, 17 - 3, May. Retrieved January 10, 2006 from www.barbara.nussbaum.com/doc/Perspectives050703.pdf

STRAUSS, Anselm; Corbin, Juliet (1990) Strategies of qualitative inquiry, Newbury Park: Sage

VALLADE, Delphine (2004), «Mutations et effritement des frontières entre travail et hors travail: la productivité du temps libre». Retrieved February 16, 2005 from http://seminaire.samizdat.net/article.php3?id article $=25$ 